(Die Preisträgervorträge wurden in einer Plenarsitzung am 14. November 2014 vorgetragen)

Der Preis für Geisteswissenschaften 2014 wurde Berenike Herrmann, Göttingen, in Anerkennung für ihre Arbeiten auf dem Gebiet der korpusgestützten Metaphernforschung verliehen.

\title{
Berenike Herrmann
}

\section{Metaphern im akademischen Englisch: Eine kognitiv-korpuslinguistische Studie}

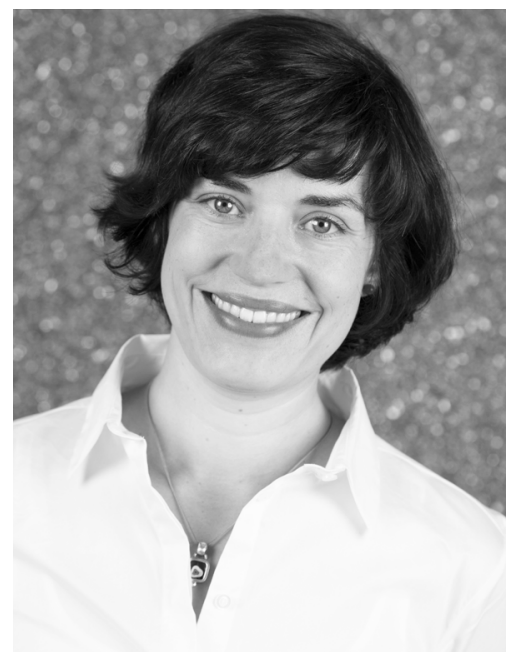

Berenike Herrmann, wissenschaftliche Mitarbeiterin an der Philosophischen Fakultät der Georg-August-Universität Göttingen, Trägerin des Preises für Geisteswissenschaften 2014
I would like to start by acknowledging some forces that have enabled my research: I extend a great thanks to my research group at the VU University Amsterdam, especially to my supervisor Prof. Gerard Steen! My dissertation would not have been possible without its basis in our collaborative research. In this respect, I would also like to thank Prof. Gerhard Lauer, who is another outstanding promoter of interdisciplinary and collaborative humanities research, and a both prudent and inspiring supervisor.

Now, to really start the tour, let us briefly return to the beginnings of what we understand as modern academic discourse: the Scientific Revolution in the 16th/17th Century. The protagonists of the scientific revolution, for example Bacon, Hobbes, and Locke, had very specific ideas about the dos and don'ts of academic writing. Their postulations can be summed up in the ideal of a "plain style“, a style that should avoid figurative ornatus, and as such, metaphors. Words in academic use, such is the postulation, should have a direct relation with ideas and objects of the world. Here's one historical quote:

Metaphors, and senseless and ambiguous words, are like ignes fatui; and reasoning upon them, is wandering amongst in-numerable absurdities [...]. (Thomas Hobbes in the Leviathan, 1651) 
Hobbes, as many others, saw metaphor as an indirect and therefore incorrect form of language and thought (for a differentiated discussion of Hobbes's view on metaphor, see Musolff, 2005). Until today, figurative language has had a problematic status in academic discourse, as can be seen for example in the authoritative style manual by the American Psychological Association (APA), with its advice to „use metaphors sparingly“ (2010, p. 70).

However, some scholars have suggested a different take. One important more recent school, cognitive linguistics, has proposed that metaphor is not only present in literary texts, but indispensable in any kind of communication, including academic discourse (cf. Lakoff \& Johnson, 1980). From this perspective, one can show that even in Hobbes' quote, metaphor (and simile) is present:

Metaphors, and senseless and ambiguous words, are like ignes fatui; and reasoning upon them, is wandering amongst in-numerable absurdities [...] (metaphorically used words underlined).

The painting in figure 1 shows an ignis fatuus, a foolish fire (another common name in English is Will-o'-the-wisp; German Irrlicht). It is a light that appears and disappears spontaneously in nature, sometimes misleading travelers. In the picture, we can also see an instance of non-metaphorical wandering.

So far, I have sketched out two basic perspectives on metaphor in academic discourse, one wary of metaphor, the other one embracing it. In the following, I will very briefly delineate my research design, explain key terms and then report my empirical findings concerning the actual extent and the forms of metaphorical word use in academic texts. Questions that I will tackle are How many metaphors are there? What forms do they have? What functions do they carry out?

\section{Research design}

In order to be able to make valid claims, I examined metaphor in academic discourse in comparison with three other main registers of English: news, conversation, and fiction. Together with my colleagues I constructed a database that comprises approximately 190,000 words of British English (from the British National Corpus, cf. Steen, Dorst, Herrmann, Kaal, \& Krennmayr, 2010). With an iterative procedure ensuring intersubjectivity, reliability and transparency, we coded the entire database manually for metaphor and word class, on a word-by-word basis. For example, the word wandering from the Hobbes quote would have been marked as a verb - and as metaphorically used. 


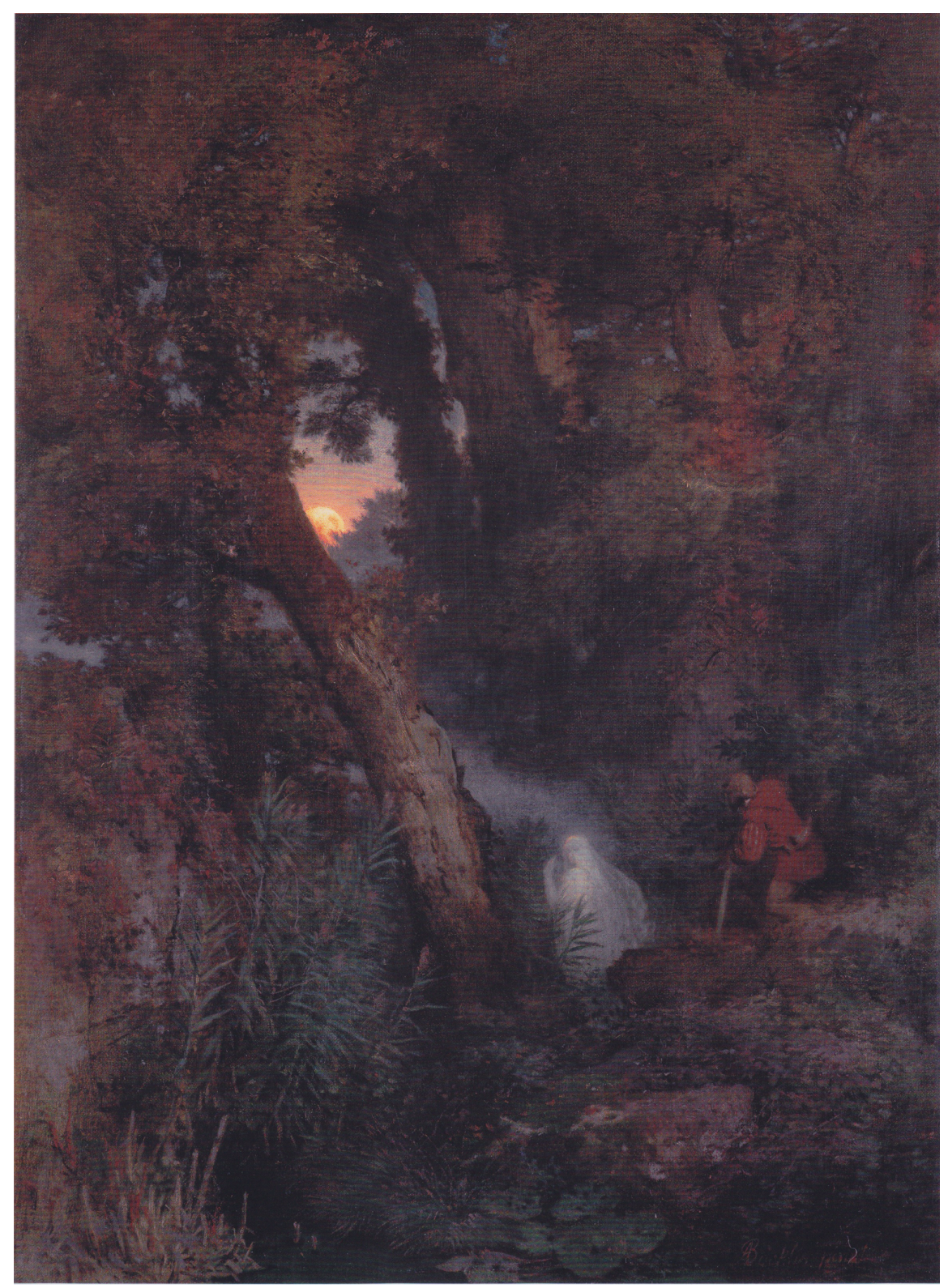

Fig. 1. An ignis fatuus (Das Irrlicht). Source: Arnold Böcklin [Public domain], via Wikimedia Commons. 


\section{Key terms}

In my work, ,academic discourse“ means essentially the register of written academic prose. Its primary goal is to transmit detailed and precise information, to develop arguments and give explanations. This is why academic prose has been termed an ,informational register“, as opposed for example to the „involved“ register of conversation, with its interactive and affective purposes and highly constrained production circumstances (cf. Biber 1988).

When it comes to metaphor, there have been literally hundreds, if not thousands, of different approaches since Aristotle noted the phenomenon of metaphérein - a „transference“ of meaning. Today, I cannot even begin to do justice to the wealth of studies! However, let me say this much: Aristotle’s definition, „Metaphor consists in giving the thing a name that belongs to something else" (Aristotle, 1895, Chapter 21) is still in use today, about 2,300 years later. Although not defining metaphor quite as broadly as Aristotle, cognitive linguistics has a similar concept. To Lakoff and Johnson, ,the essence of metaphor“ is „understanding and experiencing one kind of thing in terms of another" (1980, p. 5). With its emphasis on situated experience and cognition as relevant to the workings of the language system, I take this definition as my starting point. However, it is still too broad, for example because it conflates thought and language. Therefore, in my research, I differentiated four levels of analysis: the level of the linguistic forms (words and phrases, at the language surface), the level of concepts (underlying the linguistic forms), the level of socio-communicative functions, and, finally, the level of text processing and cognition.

To illustrate the operational definition that I used, let us focus on the verb attack in the text fragment „This view, as we shall see, has been attacked“. The contextual meaning of attack is to ,criticize strongly“ (cf. Macmillan, also in the following). But there is also a more basic meaning, which is more concrete and bodily-oriented: ,use violence to harm physically‘. Both senses are similar, yet substantially different. According to this operationalization of similarity and contrast in one word at a time, we can establish that attack is metaphorically used in this context (cf. Pragglejaz Group, 2007; Steen, Dorst, Kaal, et al., 2010).

What is more, the indirect word use in context indicates a potential underlying cross-domain mapping, such as: argument is physical fight. This is the conceptual level. Another example of metaphor in academic texts is the preposition in. In a temporal sense, it means something like, during a particular period or year'. Yet, as we can see, the temporal meaning can be contrasted with a more basic meaning, ,inside a container'. An underlying conceptual mapping may be reconstructed: time is space. 


\section{Findings}

The next stop of our tour is at the statistical analyses. I tested how metaphorical language is spread across the four registers and the word classes, and whether observed differences are significant. Here are the results: Academic prose uses more metaphors than conversation and fiction, and also news! Its proportion of metaphors is $18.5 \%$, followed by $16.4 \%$ in news, $11.9 \%$ in fiction, and $7.7 \%$ in conversation. I also looked into different sub-categories of academic prose, such as social sciences, natural sciences, and the humanities and found that metaphor is relatively evenly spread across them. This is surprising, considering the skeptical note on metaphor and tropes in academic style manuals. Metaphor seems to play a crucial role in the abstract and complex state of affairs that is academic discourse.

Let us probe the results a bit further, factoring in word classes. We know from linguistic research that word classes spread unevenly across the different registers. So, how is metaphor distributed across them in academic prose?

The three word classes that are most common in metaphorical use are prepositions (in), verbs (to attack), and nouns (this view).

Then, three others, adjectives (clear), adverbs (roughly), and demonstrative determiners (this), are in comparison (within academic prose) only average.

Table 1 shows the proportion of metaphor-related words across word classes and register (for more details, also on the statistical models, see Herrmann, 2013, Chapter 5).

In order to enrich these findings, I looked at the communicative functions of word classes (Biber, S. Johansson, G. Leech, S. Conrad, \& Finegan, 1999). Here is what I found in a nutshell: In academic prose, metaphors exert a particular range of textual and ideational functions (cf. Biber et al., 1999). This means that across all word classes, they cater to the textual packaging of information (e.g., distinction between two theories. In many word classes, metaphors participate in establishing and specifying the content of the text, which is often abstract and complex (flow of current). They control the interpretability of words (strong association), and forge exact links between words and bigger units of the discourse (e.g., it takes the following steps; for a comprehensive discussion, see Chapter 6 of my dissertation). This range of functions could be termed, informational'.

The analysis suggests, however, that the observed metaphors also perform ,social' or ,rhetoric' (personal and interpersonal in Biber's terms) functions, for example in persuasive argumentation (e.g., erosion of civil rights), in conveying personal stance, and in illustrative explanation. Yet, regardless of whether the goals are ,informational' or ,social', metaphor in academic prose is gener- 
Table 1. Percentages of Metaphor-related Words (MRWs) Within Each Word Class in Each Register

\begin{tabular}{lrrrrr}
\hline Word class & $\begin{array}{l}\text { Register } \\
\text { Academic }\end{array}$ & News & Fiction & Conversation & All registers \\
\hline AJ & $17.6 \%$ & $21.0 \%$ & $19.4 \%$ & $13.3 \%$ & $18.4 \%$ \\
AV & $10.1 \%$ & $11.0 \%$ & $9.3 \%$ & $7.5 \%$ & $9.1 \%$ \\
CJ & $1.4 \%$ & $0.9 \%$ & $1.0 \%$ & $1.5 \%$ & $1.2 \%$ \\
DT & $8.1 \%$ & $5.9 \%$ & $7.6 \%$ & $15.6 \%$ & $8.9 \%$ \\
N & $17.6 \%$ & $13.2 \%$ & $10.5 \%$ & $8.3 \%$ & $13.3 \%$ \\
PR & $42.5 \%$ & $38.1 \%$ & $33.4 \%$ & $33.8 \%$ & $38.0 \%$ \\
V & $27.7 \%$ & $27.6 \%$ & $15.9 \%$ & $9.1 \%$ & $18.7 \%$ \\
RE & $2.6 \%$ & $2.5 \%$ & $0.9 \%$ & $0.2 \%$ & $1.1 \%$ \\
All word classes & $18.5 \%$ & $16.4 \%$ & $11.9 \%$ & $7.7 \%$ & $13.6 \%$ \\
\hline
\end{tabular}

Note. $\mathrm{AJ}=$ =Adjectives; $\mathrm{AV}=$ Adverbs; $\mathrm{C}$ = Conjunctions; $\mathrm{DT}=$ Determiners; $\mathrm{N}=$ Nouns; $\mathrm{PR}=$ Prepositions; $V=$ Verbs; $R E=$ Remainder. Scores are percentages of number of occurrences of MRWs as opposed to non-MRWs within the word class. (The percentages of non-MRWs are omitted from the table in order to keep it concise.) For example, among the adjectives of academic prose, there are $17.6 \%$ MRWs ( $82.4 \%$ non-MRWs), among the adjectives of news, there are $21 \%$ MRWs (79\% non-MRWs), and among adjectives across all registers, there are $18.4 \%$ MRWs $(81.6 \%$ non-MRWs).

ally used in a quite inconspicuous way, which may eventually explain its ,nonmetaphorical feel'.

We have so far mostly looked at metaphors that are indirectly used - such as attack. However, others are directly signaled in the lexis, such as „Metaphors are like ignes fatui “ in the Hobbes quote. These so-called direct metaphors (including similes) are logically true (e.g., An atom is constructed like the solar system). One might assume that with its truth-oriented goals, academic prose actually makes ample use of such constructions. However, the analysis showed that this is not the case.

Direct metaphors are less frequent in academic prose than in most other registers (Figure 2 depicts the distribution of direct metaphors across the four registers).

What is more, direct metaphors are overall extremely infrequent (the direct metaphors comprising a total of only $\mathrm{N}=336$ words across registers). $99 \%$ of all metaphors of academic prose are not direct, but indirect. Because direct metaphors are a more overt form of figurative language use, their factual avoidance may be related to the stylistic restrictions of a ,plain academic style" that refrains from the marked use of metaphor. 


\section{Direct Metaphor $(\mathrm{N}=336)$}

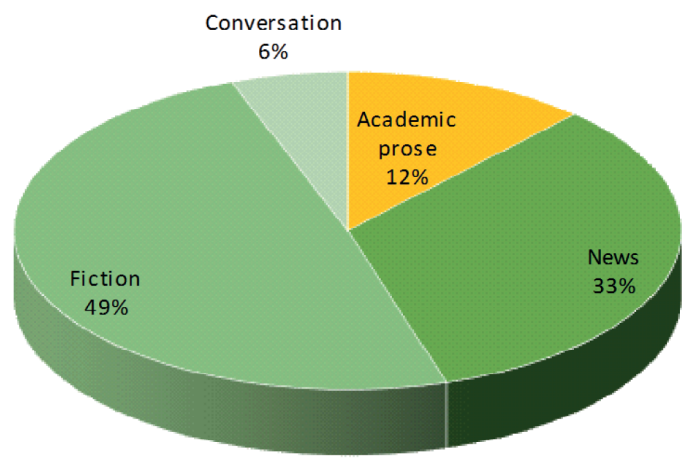

Fig. 2. Percentage of direct metaphor across four registers of English.

\section{Conclusion}

To conclude: in comparison with three other main registers of English, academic prose leads the quantitative rank order of metaphoricity. The mainly informational, but also the ,social' and rhetorical functions of academic texts appear to rely on a substantial use of metaphors across word classes. This appears not to be coincidental, but to reflect important aspects of the way in which language is set up - exploiting metaphor's potential of mapping the concrete onto the abstract, the body onto the intellectual, and space onto the non-tangible.

While similar claims have been criticized for being too vague and hard to test, my research offers new, quantitative evidence for the role of metaphor in abstract discourse. By pinning down metaphor at the level of words, applying a reliable and transparent identification procedure to a sizeable digital corpus, factoring in word classes and metaphor types, and comparing academic prose to three other registers I have shown that even such an evasive style phenomenon as metaphor can be validly empirically examined. One of the conclusions I have drawn from the data is that in academic prose, metaphors are plenty. They are used to make academic prose more coherent, exact and understandable, as well as persuasive and they are largely devoid of the polyvalence and striking force so typical of literary and especially poetic metaphor. The $18,5 \%$ work behind the scenes, as it were.

Nun bin ich am Ziel dieses kleinen Rundgangs angekommen, zurück in die Akademie der Wissenschaften zu Göttingen. „Fecundat et ornat“ - sie befruchtet und ziert: Der Siegelspruch der Akademie ist für eine Metaphernforschende sozusagen ein gefundenes Fressen. Dazu zwei Beobachtungen: Zum einen wäre die schmückende - oder zierende - Funktion der Akademie sicher auch von 
Metaphern-Skeptikern wie Hobbes nicht in Frage gestellt worden. Zum anderen bin ich mir sicher, dass der Preis eine (und dies nun wirklich metaphorisch!) befruchtende Wirkung auf die gegenwärtige und zukünftige Forschung haben wird, zu der ich einen Beitrag leisten darf.

Ich danke Ihnen, den Anwesenden, und auch denjenigen Mitgliedern der Akademie, die heute nicht hier sein können, sehr herzlich!

\section{Literatur}

American Psychological Association (2010). Publication Manual of the American Psychological Association (APA). 6th ed. Washington, DC: American Psychological Association.

Biber, D. (1988). Variation Across Speech and Writing. Cambridge: Cambridge University Press. Herrmann, J. B. (2013). Metaphor in Academic Discourse. Linguistic Forms, Conceptual Structures, Communicative Functions and Cognitive Representations. Utrecht: LOT dissertation series. (Available online at: http://dare.ubvu.vu.nl/handle/1871/43562)

Lakoff, G., \& Johnson, M. (1980). Metaphors we Live by. Chicago: Chicago University Press. Macmillan Online Dictionary for Advanced Learners of English. Online Ressource: http://www.macmillandictionary.com/dictionary/ (accessed 12 November 2014).

Aristotle. (1895). Poetics (S. H. Butcher, Trans.). London Macmillan.

Biber, D., S. Johansson, G. Leech, S. Conrad, \& Finegan, E. (1999). The Longman Grammar of Spoken and Written English. London: Longman.

Musolff, A. (2005). Ignes fatui or apt similitudes? - the Apparent Denunciation of Metaphor by Thomas Hobbes. Hobbes Studies, XVIII, 95-111.

Pragglejaz Group. (2007). MIP: A Method for Identifying Metaphorically Used Words in Discourse. Metaphor and Symbol, 22 (1), 1-39.

Steen, G. J., Dorst, A. G., Herrmann, J. B., Kaal, A. A., \& Krennmayr, T. (2010). VU Amsterdam Metaphor Corpus. Retrieved from: http://www.ota.ox.ac.uk/headers/2541.xml

Steen, G. J., Dorst, A. G., Kaal, A. A., Herrmann, J. B., Tina, K., \& Pasma, T. (2010). A Method for Linguistic Metaphor Identification: From MIP to MIPVU. Amsterdam and Philadelphia: John Benjamins. 